\title{
Collective Redress: The Need for New Technologies
}

\section{Hodges ${ }^{1}$}

Received: 16 May 2018 / Accepted: 2 August 2018 / Published online: 28 August 2018

(C) The Author(s) 2018

\begin{abstract}
After many years of debate on collective redress, the European Commission has proposed to introduce a representative mechanism to be controlled by public bodies and consumer associations that satisfy certain criteria. However, the Commission has only considered a single mechanism (the litigation-based class or representative action), which is in fact "old technology." There are several other mechanisms that deliver collective redress - new technologies. The first is the partie civile mechanism in which a civil claim "piggy backs" onto a criminal conviction. The most important mechanisms are "regulatory redress"-where a regulatory authority intervenes and agrees or orders redress to be paid - especially if coupled with an ombudsman scheme (not arbitration-based alternative dispute resolution (ADR) schemes). The regulatory redress mechanism was proposed by the Commission in the revised Consumer Protection Cooperation (CPC) Regulation but what emerged was not ideal. All these mechanisms have recently been evaluated against criteria such as their speed, cost, and ability to deliver effective outcomes. The empirical data clearly demonstrate that the new technologies are better than the old technologies. The new technologies also deliver more functions than the old: not just resolution of a dispute or delivery of redress but also assistance to consumers and traders and the ability to aggregate data on trading issues that is fed back to improve compliance, behaviour, and performance in the market place. This evidence leads to the conclusion that the Commission's proposals are unlikely to deliver effective collective redress for consumers. The proposed method is out of date technology, and other mechanisms are clearly preferable and should be adopted instead. Member States are permitted to maintain existing collective redress mechanisms. That will lead to considerable confusion and diversity, which does not support an integrated single market. Further, the proposal will lead to a diversity of available mechanisms between Member States and hence confusion and competition between intermediaries - forum shopping. The way forward is for the EU to adopt regulatory redress and consumer ombudsmen, rather than the old fashioned litigation model. The analysis also reveals that the Impact Assessment system has flaws.
\end{abstract}

Keywords Collective redress $\cdot$ Regulation $\cdot$ Enforcement policy $\cdot$ Consumer

\section{Hodges}

christopher.hodges@ csls.ox.ac.uk

Back Affiliation 
It is axiomatic that redress should be paid whenever due. Too often, redress is either not paid, or is reduced by transactional costs (intermediaries' rents), or is delayed so long that the restorative effect is reduced or irrelevant. Speed, cost, and effective outcomes are paramount in delivering redress. In 2016, the European Commission found that almost a third of consumers decided not to act upon their problem (despite feeling it would have been legitimate), and that the main reasons for not complaining were that the sums involved were too small (34.6\%) and that it would have taken too long (32.6\%) (European Commission 2017). The issue, therefore, is to select a mechanism that delivers redress swiftly, effectively, efficiently, without false results or abuse, with no or minimal costs or barriers for claimants to access the procedure, without significant reduction in the redress paid to claimants through intermediaries' or transactional costs, and with proportionately low overall transactional cost for payers.

Collective redress is a good example of the phenomenon of multiple debates existing in silos. Those who are familiar with civil procedure focused on litigation solutions for delivering redress, namely class actions, collective actions, and representative actions. Those who work in public law, or in alternative dispute resolution (ADR), focus on other mechanisms with which they are familiar. This can lead to a series of enclosed debates that can fail to consider the true range of mechanisms that exist or to undertake a comparative review of their advantages and disadvantages. They can focus attention on a particular technique (e.g., litigat ion) rather than the desired policy outcome (delivering redress). Further, debates tend to be polemical, whereas policy ought to be based on sound empirical evidence.

This article aims to bridge that gap. Part A summarizes four major techniques for delivering collective redress (financial compensation): private collective litigation, the partie civile mechanism (a civil claim piggy-backing on a criminal prosecution), the involvement of public regulatory authorities (either through the power to order redress, or start a collective court claim, or merely through the power of general enforcement authority), and a form of ADR namely consumer ombudsmen. A summary is then given of the comparative empirical evidence, which indicates that the regulatory redress and consumer ombudsman techniques (new technology) significantly outperform the other techniques (old technology). It is also noted that the new technologies deliver a wider range of desirable functions and outcomes than just dispute resolution. Against that background, Part B summarizes two European developments: the 2018 Commission Proposal for collective damages based on an extension of an injunctions mechanism, and the 2017 adoption of a technique that is close to regulatory redress. Various issues with the collective redress proposal are noted, before a wider analysis of policy issues in Part C. Part D concludes.

\section{A. The Major Techniques}

\section{Collective Litigation}

The vast majority of consumer claims involve very modest sums (Hodges 2014), which fall below the cost-benefit threshold for investing money or time in a legal claim, even with the benefit of cost insurance and low or predictable costs. Efforts have been directed at overcoming the defects of the litigation model (access, cost, complexity, delay) through "going small" (small claims processes), "going large" (aggregation through collective actions), or going to mediation. None of these options have proved to be successful in delivering collective redress. For example, the European 
Union EU Small Claims Procedure ${ }^{1}$ has not been able to respond to individual small claims (European Commission 2013, 2014; Onțanu 2017). The 2017 revision seems highly unlikely to alter its extremely low usage (Kramer and Kakiuchi 2015). No Member State has been able to devise a collective small claim procedure.

The aggregation of multiple individual private claims should lower the cost-benefit threshold at which litigation is viable and hence increase efficiency, judicial economy and access to justice (Voet 2017). However, the empirical evidence from many cases in different European jurisdictions indicates that those theoretical advantages have proved to be elusive in practice. The European Commission stated in 2017 that the collective action mechanism is "too complex, costly and lengthy to fully reach its objectives."2 The United Nations Conference on Trade and Development (UNCTAD) echoes that verdict: those factors "usually present significant barriers to consumers" (UNCTAD 2017). The central problem with collective litigation models has been framed as to balance providing "access to justice" for consumers or other claimants with the risk of abuse. ${ }^{3}$ Both these phenomena undermine the confidence in rule of law. ${ }^{4}$ Those who fund collective litigation (typically intermediaries acting in their commercial interests, rather than those who have suffered harm) find the costs and funding issues intimidating and success uncertain. In some procedures, claims do not succeed, or costs prevent cases being brought. However, the result may be that some defendants are allowed to retain possibly large illegal gains. The risk of abuse arises in private litigation where the combined weight of financial pressure on defendants caused by the high costs and high numbers of potential claimants outweighs the cost of defending an unjustified claim. This financial pressure can sometimes force defendants to settle irrespective of the validity of individual claims - a "blackmail settlement." A model in which issues of law are decided before the validity of individual claims is assessed can be exploited to force a settlement in which the true number of valid claims is lower than it appears. ${ }^{5}$

The drawbacks of collective litigation have long been recognised by the Commission ${ }^{6}$ and the European Parliament. ${ }^{7}$ In particular, the leading class action model of the United States of America (USA) has been considered to involve abuse as a result of a "toxic cocktail" of inherent forces. In response, the European Commission's 2013 Recommendation on collective redress ${ }^{8}$

\footnotetext{
${ }^{1}$ Regulation 861/2007 of 11 July 2007 establishing a European Small Claims Procedure OJ 2007, L 199.

${ }^{2}$ Inception Impact Assessment, A new deal for consumers-revision of the Injunctions Directive (European Commission, 31/10/2017); Ares(2017)5324969, citing study supporting the assessment of the implementation of 2013 EC Recommendation on collective redress.

${ }^{3}$ Commission Recommendation of 11 June 2013 on common principles for injunctive and compensatory collective redress mechanisms in the Member States concerning violations of rights granted under Union Law (2013/396/EU), recital 15, referred expressly to the need to "avoid the development of an abusive litigation culture in mass harm situations," and recital 20 stated "in order to avoid an abuse of the system and in the interest of the sound administration of justice, no judicial collective redress action should be permitted to proceed unless admissibility conditions set out by law are met" (emphasis added).

${ }^{4}$ The Commission asserts that its 2018 Proposal strikes this balance: proposal for a Directive on representative actions for the protection of the collective interests of consumers and repealing Directive 2009/22/EC, $\operatorname{COM}(2018)$ 184, 11.4.2018, Explanatory Memorandum, p 4.

${ }^{5}$ See case studies in Hodges (2001).

${ }^{6}$ Joint information note. Towards a coherent European approach to collective redress: Next Steps, SEC(2010) 1192, 5 October 2010; Commission Staff Working Document. Public Consultation: Towards a coherent European approach to collective redress, SEC(2011)173 final, 4 February 2011.

${ }^{7}$ European Parliament resolution of 2 February 2012 on "Towards a coherent European approach to collective redress," 2011/2089 (INI), 2 February 2012.

${ }^{8}$ Recommendation 2013/396 of the European Commission of 11 June 2013 on Common Principles for Injunctive and Compensatory Collective Redress Mechanisms in the Member States Concerning Violations of Rights granted under Union Law (2013 OJ (L 206) 60 (EU)).
} 
asserted that abuse would not be allowed in the EU and it could be prevented by ensuring that a (long) list of safeguards should be enshrined in any collective action mechanism. However, the Recommendation has simply not been adopted by any Member State. Each national model adopts a different mixture of procedures and safeguards, based simply on the outcome of particular national political debates. Thus, each national model is a political compromise. However, this diversity still produces the result that no one model appears to be better than any other in either overcoming the barriers and risks of abuse or the barriers to delivery of redress.

The empirical evidence from cases to date is disappointing. Whilst controls on entry to collective action can be relaxed, attracting more cases, collective litigation still remains strikingly lengthy and costly (Hodges and Voet 2018, pp. 43-152). In some jurisdictions, a considerable number of class cases fail to satisfy the criteria for certification and are dismissed at initial judicial scrutiny. ${ }^{9}$ In many jurisdictions, collective litigation takes years ${ }^{10}$ and is only possible with significant funding, which is generally unavailable from states (through legal aid) and can only come from lawyers and/or third party funders. Reliance on private funders has a number of consequences, including selection of cases that have a high chance of success and likelihood of delivering large profits for the funders. Many small consumer claims are unlikely to satisfy such commercial criteria.

The total number of collective litigation cases in Europe remains low. A few high-profile cases can give the opposite impression, but many mass consumer issues are not raised in litigation, still less resolved.

\section{The Civil-Criminal Piggy Back}

A civil claim can "piggy back" onto a criminal prosecution, as a partie civile. Civil claimants bear no expense of investigating a case, instructing lawyers, or prosecuting the allegations. If the defendant is convicted the claimants' civil claims may be processed by the criminal court. The piggy back mechanism carries obvious possibilities for efficiency and for reduced cost for claimants. It depends on defendants being prosecuted, and convicted under the higher burden of proof of criminal law, and those defendants being convicted who have sufficient assets or are insured. The mechanism exists in a large number of Member States.

However, the technique has limitations. Most infringements of consumer law do not constitute a criminal offence in most jurisdictions. ${ }^{11}$ In most Member States, the criminal judge may decline to process the civil claims. Voet has shown that the mechanism is only used significantly where the criminal judge is required to process the civil claims, as in Belgium and France (Voet 2013a, 2013b, 2015). Successful examples of the piggy back technique, and of delivery of collective redress, are the claims resulting from the Gellingen gas explosion in 2004 (Lagasse and Palumbo 2013; Moreau 2010; Philippe 2015).

\footnotetext{
${ }^{9}$ It appears that despite heroic activism by lawyers in Italy and Poland in bringing class actions under new legislation, around half are dismissed on certification (Hodges and Voet 2018), Chap. 3.

${ }^{10}$ A striking example is the Deutsche Telekom case that spawned the Kapitalanleger-Musterverfahrensgesetz

(KapMuG) in Germany, which continues after 15 years.

${ }^{11}$ Belgium and France are exceptions.
} 


\section{Regulatory Redress}

"Regulatory redress" describes where the involvement of a public regulatory or enforcement body (referred to here generically as a regulator) results in redress being paid to those who have been harmed. The situation is typically that the payer company is accused by the regulator of breach of trading law, which may include infringements in advertising, provision of information, product or service safety, acting in response to adverse information, and so on. The historical paradigm was that a regulator would either prosecute the trader for the breach, or not do so. Nowadays, regulators increasingly aim to achieve a wider range of outputs. The discussion with the trader would encompass not just cessation of the breach but also defined actions to prevent reoccurrence (or reduce the risk), deliver redress to those harmed, thereby restoring the market to its "level playing field" position (Hodges 2011). A fair competitive market must not be distorted by the effects of some actors retaining illicit gains. Thus, the underlying reasons why it is the responsibility of regulators to ensure that redress is paid include ensuring that customers are treated fairly, that those who are harmed are made whole, and that illicit gains are not retained to unbalance the market.

The involvement of public regulatory authorities in delivering redress can take various forms. Some authorities have power to pursue collective litigation, such as in effect a class action. ${ }^{12}$ Some authorities have power to order redress to be paid (with some specificity or by approving a redress scheme), ${ }^{13}$ or they may simply be able to influence businesses to agree voluntary redress arrangements against the background of a power to amend licence conditions, or general supervisory and enforcement powers. ${ }^{14}$ A typology of different models has been proposed (Hodges 2015a).

The effectiveness of the redress power lies partly in the fact that it is not used alone (unlike a litigation mechanism) but is one of a number of enforcement tools that the regulator has available and may invoke in a discussion on the consequences of breach of law. This wider range of powers may typically include powers to cease an infringement (injunction), to investigate and obtain evidence, to require changes in behaviour (orders or undertakings), to require redress, and to impose or seek sanctions.

The regulatory redress power is only used in some Member States, but there it is used frequently and across multiple sectors. It is striking that cases involving the regulatory redress technique are rarely resolved by the need to issue court proceedings but are settled through negotiated settlements between authorities and traders. Such agreements typically cover all issues: infringement, actions taken to reduce reoccurrence, payment of redress, and any sanction.

In Denmark, the "Forbrugerombudsmanden", usually called "Consumer Ombudsman" in English, may bring a class action in the Market Court on behalf of affected consumers, on an "opt out" basis for claims up to $270 €$ and beyond that threshold on an opt-in basis only (Hodges 2008). ${ }^{15}$ The Forbrugerombudsmanden has relied on this power in reaching negotiated settlements in many cases since 2005 (Hodges and Voet 2018). In Finland, the equivalent "Consumer Ombudsman" has "merely" an opt in class action power, but has still regularly used his authority to negotiate redress payments.

\footnotetext{
${ }^{12}$ E.g., the Danish Consumer Ombudsman, discussed below.

${ }^{13}$ E.g., the British financial and other regulators discussed below.

${ }^{14}$ E.g., Licencing regimes exist in various sectors, such as energy, telecoms and financial services: see the Italian banking and energy examples discussed below. In the UK, Deferred Prosecution Agreements have been used in some cases: the Crime and Courts Act 2013, s. 45 and Sch. 17.

${ }^{15}$ Class Actions Act 2007, Act No 181 of 28 February 2007.
} 
In UK (Hodges 2015a, 2015b; Hodges and Creutzfeldt 2016; Money-Kyrle 2015), a variety of powers exist including ones for the authorities covering financial services ${ }^{16}$ (where there have been many cases, typically involving large sums, and the regulator has emphasised its role in redress: Financial Conduct Authority $(2016,2018)),{ }^{17}$ communications, ${ }^{18}$ energy, ${ }^{19}$ water, ${ }^{20}$ environment, ${ }^{21}$ and competition law. ${ }^{22}$ Authorities that enforce general consumer protection law have broad powers (known as enhanced consumer measures) to bring about redress, compliance, and increasing consumer choice. ${ }^{23}$

In France, the Financial Market Authority (Autorité des Marchés Financiers (AMF)) may contact traders and issue recommendations for compensation inviting the latter to take into account the interests of their clients and suggesting compensation for those of them who have been harmed. ${ }^{24}$ Banking regulators in Italy and Ireland have delivered collective redress to consumers in settling enforcement cases. Banca d'Italia can order banks to pay redress to customers. ${ }^{25}$ In 2014 , it issued two redress orders concerning mistakes in the calculation of interest, for a total amount of 118, 506, 000€. The Regulatory Authority for Electricity Gas and Water in Italy (AEEGSI) operates two mechanisms. First, traders are required to make automatic compensation payments to customers when quality standards set by the regulator are broken. In 2016, 155, 769 such compensation payments were made for breach of the rules on continuity of electricity supply and plus 54, 238 for violation of commercial quality standards (AEEGSI 2016). Second, a trader may propose the resolution of regulatory proceedings aimed at the imposition of sanctions by proposing 'commitments' (economic compensation or other) in favour of those customers who were affected from regulation violation, so as to avoid or reduce sanctions from the AEEGSI for violation of the rules. ${ }^{26}$ In one case in 2014 , this mechanism resulted in payments of $25 €$ to each of 86,000 customers.

The European Commission itself adopted the approach in enforcement of competition law in 2013 by accepting commitments from Deutsche Bahn that included introduction of a new pricing system and paying some customers compensation. ${ }^{27}$

\footnotetext{
${ }^{16}$ Financial Services and Markets Act 2000, s. 404 and 404 F(7).

${ }^{17}$ In 2016 and 2017, enforcement cases included $£ 1.3$ billion in redress.

${ }^{18}$ E.g., Communications Act 2003, s. 94.

${ }^{19}$ Electricity Act 1989, s. 27G, and the Gas Act 1986, s. 30G. In 2015-16, nearly $£ 43$ million was secured in redress.

${ }^{20}$ Water Industry Act 1991, s. 22A(1).

21 The Environmental Civil Sanctions (England) Order 2010/1157 and The Environmental Civil Sanctions (Miscellaneous Amendments) (England) Order 2010/1159. From 28 January 2017 to 31 August 2017, civil sanctions totalling around $£ 60$ million were paid by 44 companies, of which 21 were reactive cases where the company contacted the agency: Environment Agency (2017).

${ }^{22}$ Competition Act 1998, s. 49C, as amended by the Consumer Rights Act 2015.

${ }^{23}$ Enterprise Act 2008, s. 219A, inserted by the Consumer Rights Act 2015, s. 79 and Sch. 7, Art. 8.

${ }^{24} \mathrm{http}$ ://www.afg.asso.fr/wp-content/uploads/2011/01/2011_01_25_consultation_AMF_rapport indemnisation\%20epargnants\%20et\%20investisseurs.pdf.

${ }^{25}$ Consolidated Banking Law, art. 128-ter.

26 The commitments procedure arises under art 45, paragraph 3, of Legislative Decree 93/2011. The proceedings for evaluation of commitments was defined by AEEGSI in decision 14 June 2012, 243/2012/E/com (arts16 and subsequent of Allegato A to that decision).

${ }^{27}$ Press release: Antitrust: Commission market tests commitments proposed by Deutsche Bahn concerning pricing system for traction current in Germany (European Commission 2013), IP/13/780. The company proposed to pay railway companies that it does not own a one-time retroactive refund of $4 \%$ of their latest annual traction current invoice, and to provide the Commission with the necessary data to assess if the price levels charged under the new pricing system would lead to a margin squeeze.
} 
The latest EU Consumer Conditions Scoreboard noted that "The enforcement of consumer and safety rules by public authorities is positively assessed by retailers." 28 Almost a third decided to do nothing and of those who complained, few took the matter to a public authority (6.5\%) or an ADR body (3.7\%) and even fewer to a court (1.2\%). In 2017, the EU legislated to amend the Consumer Protection Cooperation (CPC) Regulation to introduce a power for all Consumer Law Enforcement Regulators (CLERs) to "seek or obtain" remedial commitments from the trader for the benefit of affected consumers. ${ }^{29}$ This is clearly a form of regulatory redress mechanism. The idea behind the introduction of unified and comprehensive public enforcement powers for public enforcers is to introduce a one-stop-shop approach to consumer law where enforcement authorities will notify the businesses concerned of the issues, asking them to change their practices and, if necessary, to compensate the affected consumers. However, the Regulation is "without prejudice to the possibility of bringing further public or private enforcement actions under national law."30

The CPC Regulation provides that firms may propose by way of undertaking to make redress, and authorities may seek and receive remedial commitments. But authorities do not have power, unless under national law, spontaneously to impose redress. The extent to which the CPC revision includes a power to seek a court order for redress is not yet fully clear and discussed below. The enforcement powers of competent authorities include, beyond the power to shut down online offers ${ }^{31}$ (emphasis added):

a. The power to adopt interim measures to avoid the risk of serious harm to the collective interests of consumers; ${ }^{32}$

b. the power to seek to obtain or accept commitments from the trader responsible for the infringement covered by this Regulation to cease that infringement; ${ }^{33}$

c. the power to receive from the trader, on the trader's initiative, additional remedial commitments for the benefit of consumers that have been affected by the alleged infringement covered by this Regulation, or, where appropriate, to seek to obtain commitments from the trader to offer adequate remedies to the consumers that have been affected by that infringement; ${ }^{34}$

d. where applicable, the power to inform, by appropriate means, consumers that claim that they have suffered harm as a consequence of an infringement covered by this Regulation about how to seek compensation under national law; ${ }^{35}$

e. in a cross-border situation, one competent authority may request another to take necessary enforcement measures, and the requested authority shall take relevant action, and may receive from the trader, on the trader's initiative, additional remedial commitments for the benefit of consumers that have been affected by the alleged intra-Union infringement, or,

\footnotetext{
${ }^{28}$ European Commission (2017). Consumer conditions scoreboard. Consumers at home in the Single Market. 2017 edition.

${ }^{29}$ Regulation (EU) 2017/2394 of the European Parliament and of the Council of 12 December 2017 on cooperation between national authorities responsible for the enforcement of consumer protection laws and repealing Regulation (EC) No 2006/2004, art 9.4(b) and (c).

${ }^{30}$ Ibid., art 2.6.

${ }^{31}$ Ibid., art. 9.4(g) (i)-(iii).

32 Ibid., art 9.4(a).

${ }^{33}$ Ibid., art 9.4(b).

${ }^{34}$ Ibid., art 9.4(c).

${ }^{35}$ Ibid., art 9.4(d).
} 
where appropriate, may seek to obtain commitments from the trader to offer adequate remedies to consumers that have been affected by that infringement. ${ }^{36}$

f. the power to impose penalties, such as fines or periodic penalty payments, for infringements covered by this Regulation and for the failure to comply with any decision, order, interim measure, trader's commitment, or other measure adopted pursuant to this Regulation. ${ }^{37}$

In other words, the trader's willingness "voluntarily" to offer remedial action may be considerably facilitated by knowledge that the authority or court will take such voluntary action into account in deciding on enforcement action and penalties and perhaps by a discussion on the penalties to be expected in case the authority does not see any moves by the trader towards making whole what has been wrong in the past behaviour towards consumers.

With respect to this "persuasive" power, the "New Deal for Consumers" package sensibly also includes a proposal to introduce similar powers for public enforcers under all the related consumer acquis measures. ${ }^{38}$ It also proposes

that national enforcement authorities apply common criteria across the EU when deciding on financial penalties for violations of the Unfair Commercial Practices Directive ${ }^{39}$ the Unfair Contract Terms Directive, ${ }^{40}$ the Consumer Rights Directive ${ }^{41}$ and the Price Indication Directive. ${ }^{42}$ In cases where a trader violates these Directives in several Member States simultaneously (so-called 'widespread infringements ${ }^{\text {,3 }}$ ), authorities will have the power to impose a fine of at least $4 \%$ of the trader's turnover. Deterrent penalties of this sort will contribute to prevent violations and restore fairness. ${ }^{44}$

A propitious means of assisting making companies do the right thing in the interest of consumers has finally been anchored in the respective sections (c) on sanctions in these four directives, which all read uniformly:

... when deciding on whether to impose a penalty and on its level, the administrative authorities or courts shall give due regard to ... (c) any action taken by the trader to mitigate or remedy the damage suffered by consumers.

\footnotetext{
${ }^{36}$ Ibid., art 12.

${ }^{37}$ Ibid., art 9.4(h).

${ }^{38}$ Proposal for a Directive amending Council Directive 93/13/EEC, Directive 98/6/EC, Directive 2005/29/EC and Directive 2011/83 as regards better enforcement and modernisation of EU consumer protection rules, $\operatorname{COM}(2018) 185,11.4 .2018$.

${ }^{39}$ Directive 2005/29 EC of the European Parliament and of the Council of 11 May 2005 concerning unfair business-to-consumer commercial practices in the internal market and amending Council Directive 84/450/EEC, Directives 97/7 and 2002/65EC of the European Parliament and of the Council and Regulation 200/2004/EC of the European Parliament and of the Council, OJ L 149, 11.6.2005, p. 22.

${ }^{40}$ Council Directive 93/13/EEC of 5 April 1993 on unfair terms in consumer contracts, OJ L 95, 21.4.93, p. 29.

${ }^{41}$ Directive 2011/83/EU of the European Parliament and of the Council of 25 October 2011 on consumer rights, amending Council Directive 93/13/EEC and Directive 199/44/EC of the European Parliament and of the Council and repealing Directive 97/7/EC of the European Parliament and of the Council, OJ L 304, 22.11.2011, p. 64.

42 Directive 98/6/EC of the European Parliament and of the Council of 16 February 1998 on consumer protection in the indication of the prices of products offered to consumers, OJ L80, 18.3.98, p. 27.

43 The CPC regulation defines a "widespread infringement" as an infringement that affects consumers in at least three Member States; "widespread infringement with a Union dimension" are defined as practices harming consumers in two-thirds of Member States or more and amounting to two-thirds of the EU population or more.

${ }^{44}$ Communication from the Commission, "A New Deal for Consumers" COM(2018) 183, Para 3.2(a).
} 
This is a decisive change in policy, which could considerably contribute to acceleration and to less bureaucratic ways of coming to results that truly assist consumers.

It is noteworthy that the Australian Law Reform Commission has recently responded to a political perception of excessive class litigation there by proposing that the regulatory redress technique should be adopted widely in Australia instead Australian Law reform Commission (2018). Whilst the class action mechanism might continue to exist, other better techniques should be afforded priority, and the litigation option only available as a long stop.

\section{Consumer Ombudsmen}

An alternative to action in court has been developing in the past two decades, through the possibilities that ADR mechanisms have in resolving disputes (Cortés 2017; Hodges et al. 2012). Thus, arbitration is widely used in commercial and international disputes, and in many small consumer-trader disputes, sometimes employing electronic and online technology. It is used to support vast numbers of transactions undertaken on the platforms of eBay, Amazon, Alibaba, and other online traders. Another technique is mediation, although ADR can involve various other techniques such as early neutral evaluation, mini trial and so on. ${ }^{45}$ National court systems are adopting online processing techniques. ${ }^{46}$

Whilst mediation- and arbitration-based models are widely used, they are designed for processing individual cases - even in large numbers - rather than for resolving large numbers of claims that might or might not be capable of more efficient resolution if processed as a single group, perhaps by deciding similar issues of law or fact that can be applied to particular groups of claims. So, despite the emphasis of the Commission on promoting ADR in general and in relation to resolving consumer-trader disputes, ${ }^{47}$ no mediation- or arbitration-based ADR mechanism currently provides a convincing means of resolving collective issues other than by processing cases individually (which can still be effective in some cases). ADR in its traditional forms of arbitration or mediation can only deliver individual redress, absent a Dutch-style ability for a court to approve ex post a collective settlement.

However, one form of ADR does currently resolve collective cases, in a number of ways. This is a consumer ombudsman mechanism, as found in the United Kindgom (UK), Belgium, and various other Member States. This use of the term "consumer ombudsman" has to be distinguished from the usage in Nordic States as mentioned above, where the Consumer Ombudsman is the sole national public CLER. Thus, the involvement of the Nordic Consumer Ombuds entities in collective redress is classified under the regulatory redress category referred to above. The consumer ombuds entities considered here are a sophisticated model of consumer ADR. The model has only yet emerged in some jurisdictions, but in them typically operates in specific market sectors such as financial services, energy, communications, and post.

Some ombudsmen operate on an arbitration model (such as for insurance, transport and energy in Germany) but others have evolved to operate by deploying a number of dispute resolution techniques in sequence, as part of an integrated pathway that is highly efficient and effective. The ideal model would include the following techniques: providing impartial information to consumers; evaluating cases as triage; establishing a formal complaint; assembling the facts from each side; exploring opportunities for the parties to agree settlement;

\footnotetext{
45 See e.g., https://www.cedr.com/solve/ene/.

46 The Rechtwijser scheme in the Netherlands; the Online Court in England \& Wales.

47 Directive 2013/11 of 21 May 2013 on Alternative Dispute Resolution for Consumer Disputes.
} 
making a decision on the case (schemes vary on whether the decision is a recommendation or legally binding). This pathway provides swift and efficient outcomes. Cases would be resolved at each of these stages, so that the number reaching the decision stage would typically be small, whilst the number of cases resolved overall could be large.

Although consumer ombudsmen are designed to resolve large numbers of individual claims efficiently, several have developed various means of resolving mass claims:

- First, an Ombuds entity will identify the existence of similar individual claims and aggregate them so as to deliver consistent decisions, ${ }^{48}$ especially where an electronic case management system exists. In 2016 and 2017, the UK Financial Ombudsman Service (FOS) ${ }^{49}$ received 1 , 394, 379 enquiries from consumers (around 5000 each working day: 604, 278 by phone and 790,101 letters and emails), which led to a more detailed investigation of a total of 321, 283 new complaints (Financial Ombudsman Service 2017). This vast quantity of data enables systemic issues to be identified quickly and relevant responses to be taken. Other UK Ombudsmen operate in this way, for example in energy and communications.

- Second, they can develop case management procedures for processing similar cases. For example, the FOS has developed a lead case process, a test case procedure (usually on a point of law, which may be referred to court), ${ }^{50}$ and collaboration mechanism under the FCA/CMA/FOS Coordination Committee (Hodges et al. 2012).

- Third, they can take initiatives to engage relevant traders in providing mass solutions. Examples are two cases resolved by the French Médiateur of the Financial Markets Authority (AMF) in 2012 and 2016 where she proactively engaged in negotiating redress outcomes (Autorité des Marchés Financiers 2013, 2017).

- Fourth, they can refer issues to a trader, regulator or legislator. The Belgian Ombudsmen for Energy and Telecommunications have done this in various cases, sometimes as a result of identifying a systemic problem from a single case (Hodges and Voet 2018, pp. 211260). Decisions of the Italian financial ombudsman, Arbitro Bancario Finanziario (ABF) (Banca d'Italia 2015), ${ }^{51}$ make a significant contribution to the supervision of the banking system, as does the French AMF Médiateur.

An important feature is where ombudsmen and regulatory authorities are able to work together. For example, an ombudsman may identify a systemic issue from the contacts that it receives and then notify relevant traders and regulators, who may address the issue without delay. This is standard practice in many UK sectors.

\section{Administrative Schemes for Personal Injuries}

In a number of Member States, the move towards ADR is mirrored by adoption of administrative no blame compensation schemes for personal injuries. Macleod and Hodges' recent study of 40 schemes across the world found that the administrative model is far more effective

\footnotetext{
48 This requirement is in the Rules for the Swiss Banking Ombudsman.

${ }^{49}$ Established by the Financial Services and Markets Act 2000.

${ }^{50}$ The test case procedure has not been applied, although one insurance firm did seek to invoke the test case procedure over the impact of the Icelandic volcano on travel insurance claims, but the ombudsman said it was inappropriate in the circumstances of the particular case.

51 Consolidated Law on Banking (Legislative Decree no 385/1993), art. 128-bis, introduced by Law 262/2005 (Investor Protection Law).
} 
than adversarial techniques (Macleod and Hodges 2017). This model is used for virtually all medical, medicine, road traffic, and workplace injuries in Denmark, Finland, Norway, and Sweden. A personal injury scheme exists in France (ONIAM) ${ }^{52}$ and was partly copied in Poland. The more inquisitorial model of administrative schemes produces predictably swifter outcomes than adversarial models, even where they are accompanied by ADR mechanisms.

\section{Delivering Wider Functions: Market Surveillance, Regulation, and Behaviour}

An important reason why the regulatory, ombudsman and administrative mechanisms have proved to be attractive is that they deliver more functions than just dispute resolution. Litigation produces resolution of disputes and decisions applying law in individual cases, sometimes clarifying the law. It is sometimes claimed that such decisions produce deterrence and widespread changes in behaviour, but those are theoretical claims that are not supported by empirical evidence (Hodges 2015b). In contrast, well-designed regulatory, ombudsman, and administrative mechanisms deliver a wide sequence of extra functions, such as providing information and assistance to traders to address the root causes of complaints against them, and hence reduce infringements and risk. The approach is founded on encouraging cooperation between intermediaries and traders, based on information contributed by consumers, and not on a deterrent or punitive approach (Hodges and Steinholtz 2017).

Given the above, regulatory, ombuds, and administrative mechanisms have been referred to as "new technology." In delivering individual or collective redress, court-based class or representative actions are "old technology." They are slow, cumbersome, costly, inefficient, and fail to deliver satisfactory outcomes to consumer, markets, or traders, in terms of redress or changed behaviour. This is well illustrated by the cases on collective redress in Member States in the past decade.

An important feature of administrative and other compensation schemes is the no blame basis. This overcomes the reluctance of clinical professionals to share information that they fear might lead to criticism of them or their colleagues or units (Tamuz 2001). Many systems designed to ensure the safety of products or services cannot operate effectively without the input of large amounts of basic data. Thus, aviation safety is founded on a no blame principle, referred to as an "open, just culture" $" 53$ (Dekker 2007; Helmreich 1999; McCune et al. 2011), which is now included in EU legislation. ${ }^{54}$ Planes would not stay in the sky without this absence of blame throughout the industry and regulatory community.

A further example is the Swedish Patient Insurance Scheme (Landstingens Ömsesidiga Försäkringsbolag), which receives much data from clinical professionals and patients, always on a no blame basis as that is the model for providing compensation, analysis of which has

\footnotetext{
52 Office National d'Indemnisation des Accidents Médicaux, des Affections Iatrogènes et des Infections Nosocomiales: Act no 2002-303, 4 March 2002 (relative aux droits des malades et à la qualité du système de santé). Arts L. 1142-1 et seq and L.1142-22 of the Code of Public Health.

${ }^{53}$ Defined in Commission Regulation (EU) No. 691/2010 of 29 July 2010 laying down a performance scheme for air navigation services and network functions and amending Regulation (EC) No 2096/2005 laying down common requirements for the provision of air navigation services, Art. 2(k).

${ }^{54}$ Regulation (EU) No. 996/2010 on the investigation and prevention of accidents in civil aviation, recital 4: "The sole objective of safety investigations should be the prevention of future accidents and incidents without apportioning blame or liability." Even in 1994, it was provided that a safety recommendation shall in no case create a presumption of blame or liability for an accident or incident: Directive 94/56/EC, art. 10 (the prevention of future accidents and incidents without apportioning blame or liability) and recital 24 (a non-punitive environment facilitating the spontaneous reporting of occurrences and thereby advancing the principle of "just culture").
} 
enabled it to identify, feedback, and dramatically reduce the incidence of certain adverse events (Macleod and Hodges 2017, pp. 174-186). A striking example is the reduction in babies born with serious injuries. $^{55}$

These examples show the use to which aggregated data can be put in delivering safety. The same feedback mechanism has been developed by Ombudsmen, including all the leading Ombudsmen in the UK, who engage regularly with traders not just on reducing the incidence of complaints but also on the root causes of such complaints and how to address the underlying organisational culture that produces them. This approach is a fundamentally different way of affecting future behaviour and culture than the assumption that breaches of rules can be prevented by imposing deterrent sanctions on those responsible, as shown by research into behavioural psychology (Kahneman 2011; Haidt 2012; Heffernan 2011; Hodges and Voet 2018, pp. 261-282).

\section{Evaluating the Mechanisms: New Technology Wins}

Empirical research on an extensive database of mass redress case studies in Member States has clearly demonstrated the superiority in delivering collective redress of the mechanisms of regulatory redress and consumer ombudsmen. The various models were evaluated against objective criteria, set out in Figure 1. The new technologies far surpass any court-based collective action mechanisms. The difference in terms of performance is clear (Hodges and Voet 2018). In its recent review of the same range of options,

UNCTAD noted that regulatory redress "has proved to be highly effective, swift, and efficient in delivering consumer redress in both individual and collective cases" and concluded that "combinations of consumer ombudsmen and regulators using redress powers, but usually resolving problems by negotiation, can satisfy the criteria well" (UNCTAD 2017).

Two conclusions emerge so far. First, at EU level, the issue of providing redress has been more than partially addressed by enabling public authorities to seek to obtain or accept redress. Various Member States go further and either possess explicit regulatory redress powers or use their influence to deliver redress. It seems that the EU has clearly decided to favour the mechanism of public enforcement over private enforcement in relation to redress. Second, the empirical evidence is that the best mechanisms for delivering collective redress are regulatory powers plus ombudsmen. It would follow that ADR systems should shift to the ombudsman model (for various reasons, including the delivery of more functions than just dispute resolution).

\section{B. The Commission's 2018 Proposal}

The European Commission issued a non-binding Recommendation for a "European collective action" model in 2013. Whilst some Member States subsequently introduced national class action mechanisms, none adopted the Commission's model. The Commission's options were therefore to drop an attempt at harmonisation, to insist on its model, or to propose something else. In April 2018, the European Commission suddenly switched to a new approach and included a different model in its Proposal on collective redress (the Proposal), ${ }^{56}$ as part of its

\footnotetext{
${ }^{55}$ Ibid., 183. The reduction in brain damaged babies between 2008 and 2015 was from an average of 20 to five per 100, 000 live births.

${ }^{56}$ Proposal for a Directive on representative actions for the protection of the collective interests of consumers and repealing Directive 2009/22/EC, COM(2018) 184, 11.4.2018.
} 
1. Advice. To what extent does the mechanism enable consumers to access advice before or during the processing of their complaint? To what extent also does the system provide advice to traders, especially small traders who may not be familiar with the law or dispute resolution options or processes, so as to achieve swift, cost-effective and fair resolutions?

2. Identification of infringement and harm. How is it that a problem involving breach of law and/or damage has occurred is identified?

3. Identification of people harmed and due redress. Must individuals come forward, or can they be identified without coming forward?

4. Access. To what extent is the mechanism user-friendly for consumers or claimants to access?

5. Cost to access. What cost must a person who claims to have suffered harm pay, and fund, in order to access the process? Or is access free?

6. Triage. To what extent does the mechanism act as a triage to prevent unmeritorious cases or unnecessary cases proceeding further? This may include, at one extreme, preventing fraudulent claims being advanced and, at the other extreme, to swiftly resolving cases that should be resolved one way or the other?

7. Duration. How long does the mechanism take from start to conclusion (including possible appeal and enforcement proceedings)? How long does it take to resolve issues, from when they first arose (i.e. when damage occurred, before a claim was made) to final resolution?

8. Costs. How much are the gross transactional costs, and the standing costs of a process? Who bears the costs, both initially, and finally?

9. Outcomes. What is achieved? Are the outcomes the ones desired by the parties, the law, or society?

10. Compensation for loss: making whole. Is a person who has suffered harm fully recompensed? How much of an award is lost in transactional costs, e.g. of intermediaries? Are extra emotional or other costs incurred and recompensed?

11. Changes in behaviour. Does the mechanism directly produce changes in systemic behaviour that reduces the incidence or future risk of non-compliance with the law? To what extent does the mechanism, therefore, act as a regulatory mechanism?

Fig. 1 Evaluation criteria of collective redress mechanisms

"New Deal for Consumers" package. ${ }^{57}$ The Proposal is that qualified entities (QEs) should be empowered to bring representative actions in court on behalf of consumers to protect general consumer interests, covering injunctions, ${ }^{58}$ and redress. Changes in the terminology used in political debate have masked the reality of what is going on. The political terminology has changed from class action to collective action to collective redress to representative action (Hodges 2008, 2009, 2010).

The Commission's choice has been significantly influenced by two recent corporate scandals and anger ${ }^{59}$ at the subsequent dismissive attitude of companies' senior management. ${ }^{60}$ Volkswagen refused to pay compensation to European consumers or retrofit cars fitted with "defeat devices" aimed at producing fraudulent test results for noxious emissions ("dieselgate") 61 _ in contrast with its agreement with US authorities to do so. Ryanair cancelled many flights just outside the period when it would be required to compensate customers, and its subsequent failure to provide adequate information or support to stranded customers likewise annoyed authorities and politicians. ${ }^{62}$ These cases frustrated the Commission's inability to resolve such pan-EU consumer issues.

\footnotetext{
${ }^{57}$ Communication from the Commission, 'A New Deal for Consumers' COM(2018) 183, 11.4.2018.

${ }^{58}$ This would replace Directive 2009/22/EC of the European Parliament and of the Council of 23 April 2009 on injunctions for the protection of consumers' interests.

59 See Letter from M Goyens of BEUC, co-signed by 38 MEPs, to President Juncker and Commissioner Jourova, 'Time for the European Commission to legislate on collective redress', 10 October 2017.

${ }^{60}$ Some argue that the underlying issue is the culture of the organisation, which traditional enforcement will not be able to affect. See Ewing (2017).

${ }^{61}$ This case is referred to throughout the Commission's documents. The PiP case involving use of non-medical grade silicone in breast implants was another example.

62 Only the UK's Civil Aviation Authority used enforcement powers to force the airline to treat customers well.
} 


\section{Qualified Entities}

A qualified entity (QE) shall be designated by its Member State if it complies with the criteria that it is properly legally constituted, has a legitimate interest in ensuring that provisions of Union law covered by this Directive are complied with, and has a non-profit making character. ${ }^{63}$ Member States may designate a QE on an ad hoc basis for a particular representative action, at its request, if it complies with the criteria. ${ }^{64}$ Compliance with the criteria is without prejudice to the right of the court or administrative authority to examine whether the purpose of the qualified entity justifies its taking action in a specific case, ${ }^{65}$ provided that there is a direct relationship between the main objectives of the entity and the rights granted under Union law that are claimed to have been violated in respect of which the action is brought. ${ }^{66}$

Member States shall ensure that in particular consumer organisations and independent public bodies are eligible for the status of qualified entity. Member States may designate as qualified entities consumer organisations that represent members from more than one Member State. ${ }^{67}$ Member States may set out rules specifying which qualified entities may seek all of the injunction and redress measures, and which qualified entities may seek only one or more of these measures. ${ }^{68}$

A QE of any Member State may bring proceedings in the courts or administrative tribunals of any other Member State. ${ }^{69}$ Where an infringement affects or is likely to affect consumers from different Member States, the action may be brought in the competent court or administrative authority by one or several QEs. ${ }^{70}$

\section{Injunctions}

A QE may seek an injunction, or an order declaring that the practice constitutes an infringement. ${ }^{71}$ In seeking an injunction, a QE shall not have to obtain the mandate of the individual consumers concerned or provide proof of actual loss or damage on the part of the consumers concerned or of intention or negligence on the part of the trader. ${ }^{72} \mathrm{~A}$ QE may also seek measures eliminating the continuing effects of the infringement. ${ }^{73}$

\section{Redress}

A QE may seek a redress order, which obligates the trader to provide for, inter alia, compensation, repair, replacement, price reduction, contract termination, or reimbursement of the price paid, as appropriate. ${ }^{74}$ A Member State may require the mandate of the individual consumers concerned before a declaratory decision is made or a redress order is issued. ${ }^{75}$ The

\footnotetext{
${ }^{63}$ Proposal, art. 4.1.

${ }^{64}$ Proposal, art. 4.2.

65 Proposal, art. 4.5.

${ }^{66}$ Proposal, art. 5.1.

${ }^{67}$ Proposal, art. 4.3.

${ }^{68}$ Proposal, art. 4.4.

${ }^{69}$ Proposal, art. 16.1.

${ }^{70}$ Proposal, art. 16.2.

71 Proposal, art. 5.2.

72 Ibid.

73 Proposal, art. 5.3.

${ }^{74}$ Proposal, art. 6.1.

75 Ibid.
} 
QE shall provide sufficient information as required under national law to support the action, including a description of the consumers concerned by the action and the questions of fact and law to be resolved. ${ }^{76}$

Instead of a redress order, Member States may empower a court or administrative authority to issue a declaratory decision regarding the liability of the trader towards the consumers harmed by an infringement, in duly justified cases where, due to the characteristics of the individual harm to the consumers concerned the quantification of individual redress is complex. ${ }^{77}$ The ability to issue such a declaratory decision shall not apply in the cases where:

(a) consumers concerned by the infringement are identifiable and suffered comparable harm caused by the same practice in relation to a period of time or a purchase. In such cases the requirement of the mandate of the individual consumers concerned shall not constitute a condition to initiate the action. The redress shall be directed to the consumers concerned;

(b) consumers have suffered a small amount of loss and it would be disproportionate to distribute the redress to them. In such cases, Member States shall ensure that the mandate of the individual consumers concerned is not required. The redress shall be directed to a public purpose serving the collective interests of consumers. ${ }^{78}$

The redress obtained through a final decision under a redress order or a declaratory decision shall be without prejudice to any additional rights to redress that the consumers concerned may have under Union or national law. ${ }^{79}$ The court or administrative authority shall require the infringing trader to inform affected consumers at its expense about the final decisions providing for injunction or redress measures. ${ }^{80}$

\section{Funding-Necessary for Consumer Associations Rather than Public Bodies?}

The Proposal inherently accepts that mass litigation is only possible with external private funding, and that this may involve conflicts of interest and abuse. The QE must declare at an early stage of the action the source of the funds used for its activity in general and the funds that it uses to support the action. ${ }^{81}$ It shall demonstrate that it has sufficient financial resources to represent the best interests of the consumers concerned and to meet any adverse costs should the action fail. ${ }^{82}$ Member States shall ensure that courts and administrative authorities are empowered to assess the above circumstances and accordingly require the qualified entity to refuse the relevant funding and, if necessary, reject the standing of the qualified entity in a specific case. $^{83}$

Member States shall ensure that in cases where a representative action for redress is funded by a third party, it is prohibited for the third party:

\footnotetext{
76 Ibid.

${ }^{77}$ Proposal, art. 6.2.

78 Proposal, art. 6.3.

79 Proposal, art. 6.4.

${ }^{80}$ Proposal, art. 9.1.

${ }^{81}$ Proposal, art. 7.1.

82 Ibid.

${ }^{83}$ Proposal, art. 7.3.
} 
(a) to influence decisions of the qualified entity in the context of a representative action, including on settlements;

(b) to provide financing for a collective action against a defendant who is a competitor of the fund provider or against a defendant on whom the fund provider is dependant. ${ }^{84}$

Assistance for qualified entities ${ }^{85}$

1. Member States shall take the necessary measures to ensure that procedural costs related to representative actions do not constitute financial obstacles for qualified entities to effectively exercise the right to seek the measures ..., such as limiting applicable court or administrative fees, granting them access to legal aid where necessary, or by providing them with public funding for this purpose.

2. Member States shall take the necessary measures to ensure that in cases where the qualified entities are required to inform consumers concerned about the ongoing representative action the related cost may be recovered from the trader if the action is successful.

3. Member States and the Commission shall support and facilitate the cooperation of qualified entities and the exchange and dissemination of their best practices and experiences as regards the resolution of cross-border and domestic infringements.

\section{Promoting Settlement}

Member States shall ensure that at any moment within the representative actions, the court or administrative authority may invite the qualified entity and the defendant, after having consulted them, to reach a settlement regarding redress within a reasonable set time-limit. ${ }^{86}$ Member States may provide that a qualified entity and a trader who have reached a settlement regarding redress for consumers affected by an allegedly illegal practice of that trader can jointly request a court or administrative authority to approve it. ${ }^{87}$ Such a request should be admitted by the court or administrative authority only if there is no other ongoing representative action in front of the court or administrative authority of the same Member State regarding the same trader and regarding the same practice. ${ }^{88}$ The above settlements shall be subject to the scrutiny of the court or administrative authority, which shall assess the legality and fairness of the settlement, taking into consideration the rights and interests of all parties, including the consumers concerned. ${ }^{89}$

\section{Follow-On Mechanism}

An infringement established in a final decision is deemed as irrefutably establishing that infringement for other redress actions in the same Member State. ${ }^{90}$ Such a final decision taken

\footnotetext{
${ }^{84}$ Proposal, art. 7.2.

${ }^{85}$ Proposal, art. 15.

${ }^{86}$ Proposal, art. 8.1.

${ }^{87}$ Ibid.

${ }^{88}$ Ibid.

${ }^{89}$ Ibid.

${ }^{90}$ Proposal, art. 10.1.
} 
in another Member State shall be a rebuttable presumption in an action in another Member State. $^{91}$

\section{Safeguards}

Since before 2013, the position of the European institutions has been that safeguards are needed in collective redress litigation to guard against abuse. The Recommendation set out a long list of safeguards. ${ }^{92}$ That list of safeguards has simply been ignored in the Proposal on the ground that:

The principles in the Recommendation are self-standing and this proposal does not reproduce all procedural elements addressed by the principles. This proposal only regulates certain key aspects that are necessary for the establishment of a framework, which must be complemented by specific procedural rules on the national level. Some procedural elements from the Recommendation are not reproduced in this proposal due to its more targeted scope, which is limited to infringements that may affect the collective interests of consumers, and the pre-existing features of the representative action model in the current Injunctions Directive. ${ }^{93}$

Accordingly, the diversity in safeguards that currently exists at national level is to continue and merely be subject to a small number of minimum criteria. The Commission has abandoned its attempt to create a single EU model for collective redress and has abandoned an attempt to impose any mandatory effect of any or all of the safeguards listed in its Recommendation. It is a free for all. This will fuel forum shopping.

A study has recently found that the list of safeguards is ignored by Member States and claimed that there is a significant risk of abusive litigation at national level (Institute for Legal Reform 2017a). In a further paper, US business argued that differences in the safeguard regimes applied by different Member States were matters for concern, particularly in relation to the scope for development of forum shopping between jurisdictions (Institute for Legal Reform 2017b). A survey of 6177 consumers in six Member States found that $85 \%$ of respondents supported the introduction of safeguards for collective actions, that nearly $80 \%$ felt it was important that safeguards should be consistent across the EU, that only $5 \%$ believed that third party litigation funding (TPLF) would ensure that collective actions would operate in consumers' best interests, that $25 \%$ believed that TPLF should be banned entirely, and that $81 \%$ supported the introduction of safeguards for TPLF (Institute for Legal Reform 2017c).

The Commission's logic in proposing just five safeguards must be that those measures selected must be adequate to guard against abuse. Of the five basic safeguards, two are just framed in recitals:

- First, punitive damages are mildly banned in recitals 4 and 17 ("should be avoided") under this procedure - but are not forbidden to the extent they exist under separate national law mechanisms - so the size of the blackmail pressure is supposed not to be overwhelming.

\footnotetext{
${ }^{91}$ Proposal, art. 10.2 .

92 Under the main headings of standing, admissibility, information, reimbursement of costs of the winning party, cross-border cases, the opt-in principle, collective ADR, legal representation and lawyers' fees, prohibition of punitive damages, funding of compensatory collective redress, and collective follow-on actions.

93 Proposal, p 4.
} 
On the other hand, the amount of the pressure has been significantly increased because of the ability to aggregate numbers of claimants in multiple or all Member States.

- Second, control of the mechanism is limited to intermediaries that satisfy criteria that they are legally constituted, have a legitimate interest and have a "non-profit character."

- Third, the QE should disclose its funding and courts may determine if the purpose of the QE justifies it taking the particular action.

- Fourth, a TPLF must not influence decisions.

- Fifth, recital 18 mentions that "the court or administrative authority should verify at the earliest possible stage of the proceedings whether the case is suitable for being brought as a representative action, given the nature of the infringement and characteristics of the damages suffered by consumers concerned"- - but the articles do not contain anything about this core safeguard, which is strongly elaborated in all other jurisdictions that have class actions.

Apart from the fifth element, these criteria are essentially irrelevant for public authorities and are only included to try to regulate consumer associations. In fact, the result is that the barrier to becoming a QE is very low. If a Member State decides to allow any consumer association, it must approve any one that applies to be approved, subject to deciding which QEs may exercise an injunction and/or a redress power. It must also designate an ad hoc vehicle for a particular representative action if it satisfies the designation criteria - and the right to decide if it may exercise a redress power appears not to apply in that situation, so the ad hoc vehicle has a free run.

Many questions arise. Will these minimum criteria be effective? May they be supplemented by other national provisions? If, what other criteria will be applied? The QE criteria do not include only to bring justified actions that have adequate merit. How is a prohibition on TPLFs influencing decisions to be policed? How are infringements to be identified? Is it in the interests of the TPLF or of the QE to reveal situations that ought to be scrutinised? Is this a significant step towards extensive funded litigation that will prove to be uncontrollable? Have uncontrollable elements been let out of Pandora's box?

The provisions on funding contain some conundrums, which may raise irreconcilable inconsistency. QEs must in effect have a non-profit character ${ }^{94}$ (does that "character" prohibit all profits?) but must demonstrate that it has adequate funding to represent consumers and to meet any adverse costs should the action fail. ${ }^{95}$ On the other hand, Member States must ensure that procedural costs do not constitute financial obstacles for QEs to effectively exercise the right to the measures. ${ }^{96}$ How many consumer associations might not normally have adequate internal funds for extensive litigation? Most? Are Member States likely to reduce litigation costs, excuse QEs from paying costs, or pay for legal aid for these cases? Do Member States effectively have to fund such litigation? Should we expect claims against Member States for failing to comply with this provision?

\section{Implementation: Proliferation and Confusion Rather than Simplification?}

Member States have a number of discretions in implementation. Hence, there will be divergences between the regimes in Member States. Such divergences risk forum shopping between

\footnotetext{
${ }^{94}$ Proposal, art. 4.1(c).

95 Proposal, art. 7.1.

${ }^{96}$ Proposal, art. 15.1.
} 
States. The main permissible variations, and hence elements that might be subject to challenge in individual cases, are:

1. Are the powers exercised by a court or an administrative authority, or both?

2. Are there national rules on which QEs may seek which measures?

3. Which QEs can seek a redress order?

4. Can a QE be designated on an ad hoc basis?

5. Should the court or administrative authority examine whether the purpose of the QE is legitimate?

6. Does the QE satisfy the minimum criteria?

7. Does the QE's purpose justify it taking the particular action?

8. Is the mandate of individual consumers required?

9. Is the court or administrative authority empowered to issue a declaratory decision instead of a redress order?

10. Are the criteria for ordering a declaratory order satisfied (identifiable and comparable harm, or small amounts to be paid to a public purpose)?

11. Are the losses sufficiently small? Which public purpose should benefit?

12. Has the QE provided sufficient information to support the action, including a satisfactory description of the consumers concerned and the questions of fact and law to be resolved?

13. Has the QE adequately declared its funding?

14. Is the funding legitimate, and should the QE's standing be rejected?

15. Do procedural costs constitute financial obstacles for QEs to effectively exercise the right to seek the measures?

16. May the parties request approval of a settlement?

There is huge scope here for delay in the litigation process, which will increase costs. This mechanism is not likely to satisfy the requirement of delivering redress quickly and cheaply. It will not be preferable to the existing regulatory redress model. In practice, a great deal of heat will focus on the certification stage, and there is much scope for defendants to drag out this litigation process for years. That situation is a strong echo of the practice with US class actions.

An injunction power for public authorities is to be duplicated between the CPC Regulation $^{97}$ and this Proposal. In essence, the added value of the Proposal is not only to make a second attempt at introducing a full regulatory redress power for public authorities but also to enable Member States to empower consumer associations to add redress to their injunction powers in at least some Member States. A Member State is able to choose between empowering either a public authority or a consumer association with one or both of an injunction power and a redress power. Inevitably, choices will differ.

The enforcement methods for consumer protection law vary between choice of public and private techniques, and vary between national systems. The empowerment of consumer associations follows the model of various - but not all-Member States in current enforcement of fair trading and unfair competition. For example, in some Member States, enforcement activities are undertaken by bodies where the public-private distinction can be said to be something of a hybrid. Much enforcement of unfair trading (unfair competition) law in Germany is undertaken by a trade association (the Wettbewerbszentrale (WBZ)) and consumer associations (Verbraucherzentralen) and public authorities at neither federal nor state (Land)

${ }^{97}$ Art. 9.4(a). 
levels are particularly active, save in relation to criminal activity (Hodges et al. 2012). The Proposal extends this model from use of injunctions to redress. But it is curiously unbalanced that the WBZ and trade associations have been completely omitted and only consumer associations are mentioned, not least because statistically greater enforcement is undertaken by the former than the latter, in order to ensure a level playing field for competition.

\section{Duplication, Non-Harmonisation and Forum Shopping}

The Commission's 2013 Communication stated the policy of "a horizontal approach in order to avoid the risk of uncoordinated sectorial EU initiatives and to ensure the smoothest interface with national procedural rules, in the interest of the functioning of the internal market." 98 That policy has now been abandoned. The proposed EU representative action mechanism would "not prevent Member States from adopting or maintaining in force provisions designed to grant qualified entities or any other persons concerned other procedural means to bring actions aimed at the protection of the collective interests of consumers at national level." 99

Member States may reopen debate on or amend their current arrangements for injunctions or redress as a result of this measure, especially given the political nature of such debate. The result may be that Member States in effect ignore the mechanism proposed here, as they are entitled to do, and continue their current regimes and their local development. In any event, considerable variations between Member States will continue, over the reliance on public or private models of delivering redress, and the specific arrangements that apply under each model. As noted above, this is a recipe for litigation forum shopping. When mass issues arise, it can be anticipated that there will be a race between QEs and Member States. Apart from features discussed above, considerations will include the rules on funding and costs, and the extent to which full compensation may be reduced by intermediaries' costs or in settlements.

If both public and private mechanisms exist in a Member State, as anticipated as a result of the CPC Regulation and this representative action Proposal, there may be a race between public and private mechanisms. How are such procedures prioritised? Surely the public mechanism should take precedence, and any private mechanism should only be permitted after it is clear that the public mechanism will not proceed? It is suggested that a rule is required that any procedures by any non-public entity should only be permitted after any proceedings of the public authority have been concluded definitively.

There will be competition between QEs. This will arise both where multiple QEs exist in a Member State and also where a QE designated in one Member State seeks to bring an action in another Member State. TPLFs and some lawyers will pursue their commercial interests by courting QEs, whether public authorities or consumer associations. This raises the possibility of conflicts of interest and capture. Will the safeguards be adequate to prevent this? As at September 2016 there were no less than 325 QEs under the Injunctions Directive. ${ }^{100}$ The

\footnotetext{
${ }^{98}$ Communication from the Commission to the European Parliament, the Council, the European Economic and Social Committee and the Committee of the Regions, Towards a European horizontal framework for collective redress, COM(2013) 401 final, 11 June 2013, 16.

99 Proposal, art. 1.2.

${ }^{100}$ Doc 2017/C361/01, OJ 30.9.2016; BE2; BG 9; CZ 7; DK 2; DE 78; EE 2; IE 1; GR 71; ES 28; FR 19; IT 18; CY 3; LT 1; LI 1; LU 2; HU 8; MT 7; NE 1; AT 8; PL 4; PT 4; RO 1; SL 14; SK 13; FI 9; SE 1; UK 11. According to the EUR-Lex Helpdesk, as of April 2018, a more recent update of this list, which is supposed to be updated semi-annually in the Official Journal cannot be found, and the Commission has failed to produce three issues.
} 
incidence shows that the opportunity for competition between QEs is particularly high in Germany, Greece, Spain, France and Italy.

The Proposal's model is a new invention that is completely unlike any current model in any Member State. It introduces further complexity into what is already an unsatisfactory system. In future, models of pursuing collective redress would include regulatory authorities, consumer ombudsmen, national collective actions, and QEs (from any Member State) under this new EU mechanism. This is the opposite of "Better Regulation" because good regulation consists in reduction of complexity and cost, and in simple solutions which can easily be understood by well-informed citizens.

\section{Litigation Problems: Jurisdiction, Assignment, and Limitation}

Further complications arise from the litigation basis of the proposal, which there is only space to indicate briefly. The Brussels Ia Regulation ${ }^{101}$ was intended to reduce forum shopping by giving precedence to a court previously agreed as exclusively competent by the parties over the courts seized first, but it is hard to imagine a previous agreement on the jurisdiction to be seized regarding collective claims in consumer cases. So, Brussels Ia did not change that these provisions about procedural law address individual actions and do not explicitly contemplate collective actions. On the contrary, it explicitly is not applicable (pursuant to its Art. 1 paragraph 2 lit. b) to "bankruptcy, proceedings relating to the winding-up of insolvent companies or other legal persons, judicial arrangements, compositions, and analogous proceedings." Some of the Brussels Ia provisions are difficult to reconcile with collective actions (e.g., references to "a consumer" singular) and with the "free enforcement in any Member State" concept of the Proposal (e.g. that a consumer may sue under a contract (only) in the courts of the consumer's state or the defendant's state, ${ }^{102}$ and in tort in the defendant's state or the place where the harm occurred ${ }^{103}$ ). It is necessary to clarify in the "Brussels Ia" context whether all provisions of European procedural law do not apply to collective actions (Institute for Legal Reform 2017b; Woopen 2018a), just as it is each national legislator's proprietary decision to accept or reject foreign collective procedures as it sees fit. Germany, for example, has clearly rejected conducting US class actions in German courts (Schack 2017) and sought successfully to reject serving such actions under Art. 13 of the respective Hague Convention. ${ }^{104}$ Collective procedure, due to its vast remit, obviously cannot be treated according to the current rules for single claims, as already the lis pendens principle would force all various courts seized to stay proceedings in order to find out which of them has been the first seized and whether their rulings might come into conflict. Procedures might be stalled for all of Europe by the defendant's seizing first with the matter, e.g., through a negative declaratory action, a court in a country known for slow proceedings (such as the so-called "Italian torpedo").

Furthermore, the current legislative proposal for the assignment of claims ${ }^{105}$ needs to clarify that the European rules on civil procedure cannot be derogated by assigning a claim

\footnotetext{
${ }^{101}$ Regulation (EU) No. 1215/2012 of the European Parliament and of the Council of 12 December 2012 on jurisdiction and the recognition and enforcement of judgments in civil and commercial matters.

102 Ibid, Art. 18.1.

103 Ibid, Art. 7(2).

${ }^{104}$ Napster decision of the German Federal Constitutional Court of 25 July 2003, because of the potentially extortionate quality of US class actions considering the circumstances of that case, BVerfG NJW 2003, 2598.

${ }^{105}$ COM(2018)96 Proposal for a Regulation of the European Parliament and of the Council on the law applicable to the third-party effects of assignments of claims.
} 
cross-border, i.e., even though a claim can be assigned to a new owner across the border, such claim cannot be brought in a collective procedure in the new owner's Member State but only as an individual claim following the Brussels Ia provisions for single claims. This ought to be included in the proposed provisions on the law applicable to third-party effects of the assignment of claims that have recently been subject to consultation. ${ }^{106}$

Finally, in order to ensure a consistent European system for solving cases of mass harm reasonably in the future without fuelling abuse, their treatment must be concentrated into the European system of consumer law enforcement foreseen in the CPC Regulation as outlined above. Thus, beyond confirming the national CPC authorities' and the Commission's power to sue in case of need in a court yet to be defined for collective purposes and truly fitting the objectives and operational needs, a privilege of interrupting national limitations exclusively for the benefit of measures and actions undertaken by the network of CLERs should be of the essence and is urgently required.

\section{Wider Policy Issues}

\section{Responding to Consumer Issues}

At first sight, strengthening any mechanism that delivers redress when due and upholds the legal regime is a good thing. However, reality is not as simple as that. The comparative evaluation of different options not only enables some to be revealed as far preferable than others but also raises the issue of whether allowing people to pursue several mechanisms at once in fact delivers the goals or hinders their delivery. Several points need to be considered here, raised in this part.

The empirical evidence reveals not only that most consumer issues involve small individual amounts (and can aggregate into extensive consumer detriment) but also that the number of potential issues is extensive and continuous. Examination of the activities of regulators and ombudsmen in countries where the "new technologies" are developed demonstrates just how many consumer, trader, or market issues arise and need to be addressed. In contrast, the empirical evidence from collective litigation demonstrates the appearance of addressing major consumer issues but in fact focuses simply on a small number of major individual issues, leaving many untouched. ${ }^{107}$ This creates what may be a mirage. The reality is that certain intermediaries (lawyers, funders) are only capable of addressing a small number of major issues, whereas others (regulators and ombudsmen, in countries where they are enabled to operate in particular ways, especially in combination) can address multiple consumer and trader issues on an ongoing basis. Indeed, the output of these two groups of intermediaries is facilitated precisely because of their speed of throughput: the regulators and ombudsmen deal with problems quickly, whereas the lawyers and courts take a far longer time over a smaller number of issues. Hence, the former intermediaries have capacity to deal with more issues, and a greater range of cases that involve issues that would not be attractive to those who select only cases that are likely to deliver them large commercial returns with little risk. These considerations raise the issue of which intermediaries can be relied on to raise and solve issues of general public and consumer importance.

\footnotetext{
${ }^{106} \mathrm{http} / / /$ ec.europa.eu/info/law/better-regulation/initiatives/com-2018-96_en.

107 This is apparent from comparing the volume, frequency and subject-matter of cases brought under the four main techniques noted above (Hodges and Voet 2018).
} 


\section{The Need for Intermediaries to Be Independent and to Act in the Public Interest}

No consumer association in any Member State currently has a redress power ${ }^{108}$ as the Proposal suggests for all "QEs," including the possibility for ad-hoc entities, to have the assistance of any court in the EU. No Member State has so far adopted the option of empowering a consumer association with what is in effect the power to act in the way that an opt out mechanism operates. What are the reasons for this?

The issue concerns the nature of the intermediaries. It is essential that the intermediaries who are involved can be trusted to act impartially. Some of the possible intermediaries can be trusted to act in the public interest, and consumers' interests, to stop ongoing infringements. However, not all of the possible qualifying bodies can be trusted to act in the public or consumers' interests in seeking collective redress. The Commission implicitly recognizes this by providing that Member States may choose in deciding whether public or consumer intermediaries should wield either or both of injunction and redress powers. No criteria are offered for making this decision or distinction, only a set of minimum criteria that apply to QEs generically.

Both the two mechanisms that are effective in delivering collective redress-regulatory redress and consumer ombudsmen - involve intermediaries that are - when the adversary is a private company-independent of any parties, and subject to objective governance and transparency requirements that support their acting objectively in the public interest. Neither public regulators/enforcement authorities nor regulated not-for-profit ombudsmen (unlike other potential bodies) have commercial conflicts of interest in seeking damages or costs from infringers. Hence, they can be expected to independently, only pursue meritorious cases and will not pursue or settle cases influenced by their own financial interest.

When the adversary, however, is a company owned by the very state itself, or even a public body not acting in its governmental role, the question arises how the conflict of interest of the regulatory authority or publicly supervised not-for-profit ombuds entity is to be solved. The measures taken in this respect in the UK entities, and which can be recommended as a general solution, are to consider such public bodies independent of the rest of the country's administration, to make them governed by an independent board, to equip them with a consultative panel representing various parts of national society, to require them to operate transparently in accordance with stated parameters and procedures, and to make them subject to supervision by a parliamentary committee.

Whilst consumers' interests are thus well protected by the public authority, there are, however, clear dangers in endowing non-independent private bodies - such as consumer associations or trade associations - with collective damages powers because of the conflict of interest that arises through the commercial incentives inherent in large money claims and costs issues and the risk of capture of such bodies by other commercial service providers (litigation funders and lawyers). The risk of abuse arising out of empowering such bodies is considerable, and there has already been evidence of it. ${ }^{109}$ One example is the only collective cartel damages action brought by the UK consumer association (football T-shirts) after the defendant had made redress to many customers, in which few therefore opted into the suit and

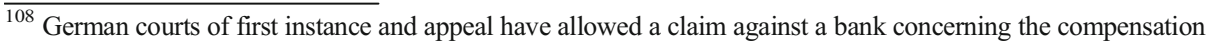
of not individually identified consumers that were affected by an unlawful practice - LG Leipzig, 10.12.2015-05 O 1239/15, Verbraucher und Recht 2016, 109; upheld on appeal by OLG Dresden, 10.4.2018-14 U 82/16. The case is now pending in the Federal Supreme Court (Bundesgerichtshof).

${ }^{109}$ E.g., the attempt to settle the Fortis case in a $€ 1.2 \mathrm{bn}$ 'opt-out' settlement on behalf of Fortis shareholders worldwide which was rejected by the Amsterdam court as favouring the claimants' association and its members at the expense of the interests of other class members, ECLI:NL:GHAMS:2017:2257.
} 
the association failed to exercise managerial control over its lawyers, who ran up a massive bill (Hodges 2008, pp. 24-26).

This is reflected in a request in Australia to the Victorian Law Reform Commission to review the rules around litigation funders to ensure that consumers are protected from unfair costs of funding litigation, stating that "[i]t is incredibly frustrating when a person wins a case, only to walk away almost empty-handed because the money has been soaked up by unfair legal fees." (Institute for Legal Reform (2017a), 61).

Both consumer associations and trade associations are effective in using injunction powers in some Member States, but neither should be given damages powers, which either are prone to abuse or to clogging up the judicial system with complicated and unnecessary amounts of civil procedures. The latter has turned out to be the case in Spain when collective actions for damages were grafted onto the previously satisfactory system of injunctions. ${ }^{110}$ The Spanish Act 7/1998 of April 13, transposing the 93/13/EC Injunctions Directive into Spanish law, was complemented in 2000 in its article 12.2 of the new Spanish Civil Procedure Act to include the possibility to add claims for compensation to collective injunctions. The inefficiency of that collective procedure became obvious in a case filed in 2010 by a consumer association to which a relevant number of consumers adhered to ask for compensation. It took six years to resolve the case in the first instance - and therefore to resolve the main cessation action - due to the many procedural issues that the presence of the individuals who aggregated their compensation claims to the cessation action caused. ${ }^{111}$ Similarly, a cessation action filed in 2010 related to allegedly abusive conduct of the defendant ABANCA in connection with the offering of swap contracts was complemented by requests for damages of 1200 clientsresulting also in a first instance decision only in $2016 .^{112}$

These dangers with collective actions for compensation contrast markedly with the efficiency of the injunctions system that has existed in Germany, in which the major role is taken by WBZ, an independent and cross-sectorial body in charge of supervising fairness in competition since 1912, so for more than 100 years, with an excellent track record. The secret to its success is its commitment to the very core of public interest, to protecting the process of competition and the proper functioning of the market, i.e., the general good as such, just as addressed in recital 3 and article 2 of Directive 2009/22/EC, and not a sum of individual interests of market participants. This is a decisive difference, and WBZ has therefore severely criticised the concept of collective injunctions in the Recommendation 2013/396/EU ${ }^{113}$ which follows the idea of bringing the action in the name and for the accounts of the persons represented - a mere concentration for procedural reasons. Whilst also in the case of a single infringement, a court can issue an injunction under Directive 2009/22/EC in the interest of the general good, this is not possible under Recommendation 2013/396/EU, which requires at least two procedures to be combined. Furthermore, Directive 2009/22/EC does not require damage to have been already suffered but just an infringement of law, whilst the concept of damage actions under Recommendation 2013/396/EU requires a damage already incurred. A

\footnotetext{
${ }_{110}$ Information contributed by A. Ferreres Comella.

${ }^{111}$ Commercial Law Court of First Instance of Madrid no.11, ECLI:ES:JMM:2016:53 of 7 April 2016.

112 Court of First Instance no. 9 of A Coruña, March 2016.

113 Stellungnahme der Zentrale zur Bekämpfung unlauteren Wettbewerbs Frankfurt am Main e.V. (abridged: Wettbewerbszentrale) zur Empfehlung der Kommission vom 11. Juni 2013 über Gemeinsame Grundsätze für kollektive Unterlassungs- und Schadensersatzverfahren in den Mitgliedstaaten bei Verletzung von durch Unionsrecht garantierten Rechten (2013/396/EU) of 14 November 2017, Berlin Office, p. 3-5.
} 
strong advantage of the concept of injunctions under Directive 2009/22/EC has been that entities can sue in their own name without having to divulge by whom they have been alerted of the infringement or to whom stopping the infringement will play out favourably. So, anonymity can be ensured, and there is no danger that undue commercial pressure from more powerful contractual partners prevents the general good from being protected. In that respect, these injunctions have the same advantage as intermediaries such as the UK Groceries Code Adjudicator in protecting suppliers to the ten large UK supermarkets from undue payment delays. $^{114}$

Thus, entities that may be appropriate for enforcing general consumer protection law backed by a power to seek an injunction are not necessarily entities that should be permitted to exercise a power to seek damages. Introducing a major financial incentive into the outcome of an activity introduces a major conflict of interest, which has been clearly shown to be the cause of abuse in the US system (Coffee Jr. 2015; Hodges 2015c). There is a risk here that the Commission may be stepping into the very elephant trap of abuse that it had earlier affirmed to avoid.

\section{Facilitating Redress and Settlement: The Need for Structures to Be Available}

If the new regulatory redress power in the CPC Regulation is intended to be a one-stop shop to resolve infringements and redress and empowers public authorities to seek or obtain undertakings for redress, why is anything else needed? It may be argued that a power to compel companies to engage with redress is needed. But having a private power exercised by actors other than the relevant public authorities would be illogical, as the powers would be used by different actors and uncoordinated. It has long been understood that large "deep pocket" companies faced with litigation may simply defend cases over several years, wearing down claimants whilst reserving funds for an ultimate settlement in which less than full compensation is paid to claimants. How is that mechanism an effective and swift tool for forcing redress? Some companies may be susceptible to reputational forces but that may take time to take effect and does not apply to all (e.g., Volkswagen, Ryanair and Poly Implant Prothèse). Surely the toolbox of enforcement powers available to public regulators is the most potent lever of compulsion, and the most appropriate.

It may be intended that the existence of the compulsory powers of the court will encourage parties to settle cases. But, it is as easy as that in large cases, or where the merits of individual cases have to be assessed? There needs to be readily available an effective mechanism that the parties can use. A theory that defendants who are found to have infringed trading law would then typically avoid mass damages claims by settling them has not been established to be valid in practice even in jurisdictions where the result would have been binding also in favour of the defendant towards all class members - which not even is the case in the Commission Proposal, where claimants can chose to accept the settlement or to pursue additional rights to redress they may have under Union or national law (Art. 8.6 Proposal). This takes away any natural incentive of mass settlements which at its core is procedural economy (Hodges 2015c). Indeed, there is extensive empirical evidence that cases of this type have not been swiftly settled. Arguments on whether an infringement has occurred, and appeals could be expected to rise in cases where the financial implications were high for defendants, leaving both parties (especially claimants) without resolution for some time. This is what typically happens at the initial

$\overline{114}$ https:/www.gov.uk/government/organisations/groceries-code-adjudicator. 
certification stage in collective litigation. One of the main reasons why fighting rather than settling is the outcome here is that the primary process (here, the court procedure) does not itself include options of triage, mediation, and decision, in that sequence. Many existing ADR schemes or individual mediators may not be attractive to both parties. In other words, the parties have to agree to go into a different system and process if they wish to negotiate. The existence of a single integrated process is what makes the consumer ombuds model distinctive from other ADR schemes and particularly effective. Consumer ombuds entities can apply the rules of either the law or an ad hoc scheme, and they can triage multiple individual cases, assessing them against acceptance criteria, before facilitating a mediated negotiation.

Accordingly, various consequences would flow from access to a damages claim being a second stage to the right to exercise an injunction power. First, this perpetuates a court-based system, rather than involving more efficient CLER or ombuds entities. It would tie both claimants and defendants into slow and costly court procedures. Second, injunctions are not a relevant first stage in every case such as infringements that have already ceased, or infringements where the initial regulatory response is wider and more sophisticated than an order to stop (Hodges and Steinholtz 2017). So, would there be an increase in injunctions threats and actions by those seeking to claim damages? Is this "wild west market" the sort that is wanted in Europe? Third, a two-stage process (finding of infringement and calculation of damages) is inappropriate for some types of case, where individual issues predominate (such as reliance of statements and personal injury causation), and has been shown to attract abusive "legal blackmail" claims (Hodges 2008).

It may be asked how mass problems are identified. This usually occurs when individual consumers come forward, with individual claims, and scrutiny of the subject matter of all claims by an expert intermediary identifies ones that are similar and that there is a systemic issue. The expert intermediary identifies that there is a mass problem, which gives rise to a number of similar individual claims. But with whom do consumers raise such problems and how can this be done in a manner that is most efficient that identifies a systemic problem as quickly as possible and determines that the issue does give rise to breaches of law that give rise to the need for redress? Who should the intermediaries be?

Such intermediaries may in theory be public authorities, not-for-profit ombudsmen, ADR schemes, consumer advisers, ECC-NET offices, consumer associations, trade associations, the media, and so on. But not all of them will perform with the same efficiency or effectiveness in identifying a systemic issue. Some of these bodies can be arranged in national landscapes so as to be more effective and efficient than others. National landscapes that have single websites providing advice and access to an ombuds system have been shown to identify trends and systemic issues quickly because they attract a sufficiently large number of individual contacts, for which the subject matter can be electronically analysed swiftly. A good example is the unique portal or access point of the Belgian Consumer Mediation Service, ${ }^{115}$ or resolver.co.uk in the UK.

After a systemic issue has been identified, it has to be resolved through a structure and process that is available and that meets the criteria set out above. The available dispute resolution process has to be permanent in order to be available, trusted, and reliable. If it is not rational that the collective damages process takes place within a court structure- because courts fail to satisfy the criteria - then the standing process has to be a pre-existing consumer

$\overline{115}$ https://economie.fgov.be/fr/themes/line/belmed-mediation-en-ligne. 
ombuds scheme or, in the case of personal injuries, an effective administrative compensation scheme.

It has, therefore, been suggested in Germany to create a "Register of Complaints" under the administration of the future CLER, in order to ensure transparency for this authority about upcoming mass damage situations (Woopen 2018b). It then could act much earlier and in a very targeted way by using a suitable instrument from its toolbox. For these tasks, the Bundesamt für Justiz (BfJ), as an authority under the supervision of the German Federal Ministry of Justice and for Consumer Protection, is ideally placed because it already has experience in exercising ADR tasks in aviation matters and is in charge of verifying and admitting consumer ADR bodies according to the Directive 2013/11 of 21 May 2013 on Alternative Dispute Resolution for Consumer Disputes, likewise for reporting on developments in Germany to the European Commission as required by that very same directive. BfJ is foreseen in the new German legislation for collective redress (Musterfeststellungsklage$(\mathrm{MFK}))^{116}$ to be in charge of a register of collective actions anyway. Instead or beyond, it should be in charge of an early warning mechanism consolidating all information coming from the various consumer consultation centres, notably the newly established consumer "watchdogs" called "Marktwächter" (market guardians) and feed suitable cases also into the EU-wide register required by article 35 of the CPC Regulation (entered into force in January 2018). This would ensure concerted action at national and EU level, whilst national consumer protection bodies will anyway be authorised to trigger so-called "external alerts" according to article 27 of the CPC Regulation for entry into the EU-wide register.

In the same way, national complaint registers and consumer ombuds schemes need to be available in every Member State so to administer mass claims with the assistance of the CPC enforcement bodies, since this network will do this far more efficiently and swiftly than courts, as the data already available for consumer ombuds schemes show.

\section{Failure to Consider all the Options}

It is axiomatic that policy should be soundly based on sound analysis of empirical evidence. The European Commission has committed itself to basing policy and rule-making on evidence and to reducing regulatory burdens. ${ }^{117}$ The Commission has adopted a Better Regulation rule that policy will be based on an objective analysis of all options and on empirical evidence. ${ }^{118}$

In relation to this Proposal, however, the Commission has failed to consider all the options. The Impact Assessment for the Proposal makes clear that the analysis did not consider

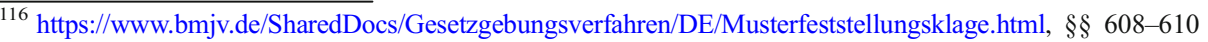
ZPO.

${ }^{117}$ Communication from the Commission to the European Parliament, the Council, the European Economic and Social Committee and the Committee of the Regions, Better regulation for better results: An EU agenda, $\operatorname{COM}(2015) 215$ final, 19.5.2015.

${ }^{118}$ Communication from the Commission to the European Parliament, the Council, the European Economic and Social Committee, and the Committee of the Regions, Better regulation for better results: An EU agenda, $\operatorname{COM}(2015) 215$ final, 19.5.2015; Communication from the Commission to the European Parliament, the European Council and the Council, Better Regulation: Delivering better results for a stronger Union (European Commission 2016), COM(2016) 615 final, 14.9.2016; Commission Staff Working Document: Better Regulation Guidelines, SWC(2017) 350, 7.7.2017; Key Question 4 ('What are the various options?' and para 2.4 ('It is important to consult widely about alternatives, think outside the box and give due consideration to all different options"); Communication from the Commission to the European Parliament, the European Council and the Council, Better Regulation: Delivering better results for a stronger Union (European Commission 2016), COM(2016) 615 final, 14.9.2016.
} 
alternative models of delivering collective redress, it has merely considered "adding collective redress" to the Injunctions Directive, without analysing the various mechanisms by which collective redress may be delivered, and only assuming a litigation model. ${ }^{119}$ This is neither good nor valid policy-making. Both the Proposal and the Impact Assessment process contain inherent flaws.

In the Commission's defence here, it proposed in 2016 to give Member State authorities what would have been an effective regulatory redress power. ${ }^{120}$ What emerged from the legislative process was a watered down power to "seek to obtain or accept" redress. However, this watered down power was regarded by experts as enabling public authorities to achieve collective redress in many cases through the regulatory mechanism. So why is anything further needed? The Proposal makes no case on that issue, and apparently does not refer in the Impact Assessment to the new regulatory redress mechanism, but puts forward an entirely new mechanism.

\section{The CPC Regulation Makes the Representative Action Proposal Superfluous}

Further, according to the Better Regulation Principles, new regulation cannot be brought forward if a problem is already solved. This situation applies here, at least according to a recent interpretation of the new CPC Regulation (Woopen 2018a).

National competent authorities are now to have, according to Article 9.4(c) of the CPC Regulation, the enforcement power "to seek to obtain or to accept commitments from the trader responsible for the infringement covered by this Regulation to cease that infringement." Pursuant to Article 10 of the same Regulation, competent authorities shall exercise - to the extent they cannot do it as per (a) directly under their own authority - their powers according to Article 10(d) "by application to courts competent to grant the necessary decision, including, where appropriate, by appeal, if the application to grant the necessary decision is not successful."

This means that a trader who does not voluntarily or under the pressure of potential fines agree to grant redress can be sued in court by the competent authority of the Member State- or the Commission itself in cases of a widespread infringement with a Union dimension ${ }^{121}$ - to agree to the redress applied for in court by the competent authority. This gives the competent authority the possibility of suggesting a suitable solution to the trader. The solution might not be a one-dimensional payment but can consist of, for example, the commitment to provide compensation in kind as the primary objective, such as the retrofitting of all VW vehicles concerned by dieselgate to the extent this is technically feasible. Substantial financial compensation could be pursued as a secondary goal only to the extent retrofitting is technically not feasible.

This in turn means that the Commission's Proposal of Representative Actions is simply in practice superfluous. What is not superfluous, though, and that is where forces should be concentrated now, is to ensure that the solution found in the CPC Regulation is safely and clearly embedded into the existing framework of European procedural law and that the entry of

\footnotetext{
${ }^{119}$ Proposal, p. 10. This records that the Regulatory Scrutiny Board initially considered that the Impact Assessment did not sufficiently demonstrate the need for legislative action at EU level on collective redress.

${ }^{120}$ Proposal for a Regulation of the European Parliament and of the Council on cooperation between national authorities responsible for the enforcement of consumer protection laws, COM(2016) 283 final, 25 May 2016.

${ }^{121}$ CPC Regulation, art. 17.3 and 17.4
} 
a case into a national register of complaints protects affected consumers from limitation of their rights and claims to the extent that the national CPC body takes action in their favour later.

\section{Conclusions}

Collective redress is an issue that has been around-and not solved-for many years. During this period, some countries have developed new technologies for regulation and controlling markets that also offer a transformation in the achievement of collective redress. It is now time to overcome silo mentality and embrace new ways of delivering goals.

The Proposal is firmly based on a model of private enforcement through court litigation, based on piggy-backing (curiously) on an injunction mechanism. Other options have not been considered or integrated in assessing the Proposal. However, further alternative options for delivering mass redress exist, as a result of significant innovative shifts in some Member States. The lesson is to "look outside the box" of litigation. These techniques have been approved by UNCTAD (UNCTAD 2017) and are spreading at Member State level and in Australia.

The critical questions are to ensure that consumers and competitors see redress being delivered swiftly, in enough instances of wrongdoing, and at proportionate cost so as to provide full compensation and rectification of market balance. These outcomes are highly unlikely with the Commission proposal for a Representative Action. The redress mechanism proposed there is still a collective litigation mechanism, which the Commission has already rightly accepted is "too complex, costly and lengthy." 122 Private collective litigation, especially if restricted to a limited pool of initiators, is incapable of responding to the number of instances where it is needed. The focus on delivering redress has been lost.

The mechanisms that deliver collective redress should be adopted; the mechanisms that do not work well should not be adopted. The mechanisms that deliver CR well are regulatory authorities with redress powers and Consumer Ombudsmen. It is time to abandon old technology that does not work well and adopt new technology that works better. The Commission was right to propose a regulatory redress power in the CPC Regulation. Several Member States use such an approach with outstanding success-even if some of their governments are even unaware that their regulators do this.

There are real dangers with the new Commission Proposal. A system that involves facilitative intermediaries who have any commercial interest in claims amounting to large sums of money risks producing the abuse that the EU has declared not to accept. This means that intermediaries must be limited to public consumer law enforcement regulators or regulated not-for-profit ombuds bodies - and shall not include trade or consumer associations, and certainly no ad hoc entities, all of which are vulnerable to capture by lawyers and litigation funders. It may be acceptable for QEs to perform some market control functions backed by injunctions, and there is particular merit in that when it comes to representing the core public interest on behalf of claimant parties who cannot divulge their identity without suffering serious harm from economic retaliation by those the injunction attacks (example of

\footnotetext{
${ }^{122}$ Inception Impact Assessment, A New Deal for Consumers-revision of the Injunctions Directive (European Commission, 31/10/2017) Ares(2017)5324969, citing Study supporting the assessment of the implementation of 2013 EC Recommendation on Collective Redress.
} 
Wettbewerbszentrale). But where claims for the payment of money are involved, a different approach is needed.

The Commission Proposal permits Member States to ignore it for their internal orders, by opting not to empower consumer associations to sue with redress powers. But defendants appear to be exposed to actions brought by foreign QEs. If all Member States adopt the proposed mechanism, there will be much greater complexity in redress models rather than simplification. That will not support integration of the single market and flies in the face of the legislative competence claimed by the Proposal.

Finally, there is a flaw in the current Impact Assessment mechanism, as it has failed to consider, let alone evaluate, all options. A convincing Impact Assessment for the Proposal is lacking and should be produced by evaluating all the mechanisms.

The Commission Proposal for a Representative Action is flawed. It should be withdrawn and thoroughly re-thought. Based on clear empirical evidence of which mechanisms work and do not work in delivering collective redress, the following model is strongly suggested:

a) All entities that collect information on market activities should pool their data on problems in the market into national complaint registries connected with the EUwide Electronic Database pursuant to article 35 of the CPC Regulation, so that systemic issues can be identified swiftly. In order to achieve this, the national landscape of consumer advice and consumer complaints (i.e., ADR entities) should be rationalised and connected with other formal market surveillance mechanisms. A small number of integrated consumer ombuds entities operating with a single national website should replace an ADR landscape that contains too many isolated ADR entities.

b) Any entity that is authorised to use injunction powers should be required to inform the entities that are authorised to use damages powers of the existence of an infringement that has been established in circumstances where similar infringements may also have occurred.

c) The power to seek damages - individually and collectively — should only be exercisable by approved independent entities that do not have any commercial conflict of interest, i.e., public authorities or not-for-profit approved ombuds entities.

At bottom, there is a question of what sort of society the EU intends to be. Is it one in which litigation is used widely, akin to US-style "adversarial legalism" (Farhang 2010; Kagan 2001), as a means of shifting money from governments and large businesses on a theory of affecting behaviour, or is it a society that encourages ethical behaviour, which leads to early identification is problems and their resolution, through rational debate and mediation?

Funding Information Research funding is received from the UK Department for Business, Energy, \& Industrial Strategy, the Swiss Reinsurance Company Limited and the European Justice Forum. Grateful thanks for comments to Dr. Herbert Woopen.

Open Access This article is distributed under the terms of the Creative Commons Attribution 4.0 International License (http://creativecommons.org/licenses/by/4.0/), which permits unrestricted use, distribution, and reproduction in any medium, provided you give appropriate credit to the original author(s) and the source, provide a link to the Creative Commons license, and indicate if changes were made. 


\section{References}

AEEGSI. (2016). Annual report. Autorità per l'Energia Elettrica il Gas e il Sistema Idrico.

Australian Law Reform Commission. (2018). Inquiry into class action proceedings and third-party litigation funders. Discussion paper.

Autorité des Marchés Financiers. (2013). AMF ombudsman's report 2012 (pp. 4-5). Paris: Autorité des Marchés Financiers.

Autorité des Marchés Financiers. (2017). AMF ombudsman's report 2012 (pp. 27-28). Paris: Autorité des Marchés Financiers.

Banca d'Italia. (2015). The banking and financial ombudsman annual report: number 5.

Coffee Jr., J. C. (2015). Entrepreneurial litigation: its rise, fall, and future. Boston: Harvard University Press.

Cortés, P. (2017). The new regulatory framework for consumer dispute resolution. Oxford: Oxford University Press.

Dekker, S. (2007). Just culture. Balancing safety and accountability. Aldershot: Ashgate Publishing.

Environment Agency. (2017). Enforcement undertakings accepted by the environment agency. London.

European Commission. (2013). Report from the Commission of 19 November 2013 on the Application of Regulation (EC) No 861/2007 of the European Parliament and of the Council establishing a european small claims procedure, COM (2013) 795 final. Brussels: DG JUST.

European Commission. (2014). Report from the Commission of 15 April 2014 on the Application of Council Regulation (EC) No 2201/2003 concerning jurisdiction and the recognition and enforcement of judgements in matrimonial matters and the matters of parental responsibility, repealing regulation (EC) No 1347/2000, COM (2014) 225 final. Brussels: DG JUST.

European Commission. (2017). Consumer conditions scoreboard. Consumers at home in the Single Market. 2017 edition.

Ewing, J. (2017). Faster, higher, farther. The Volkswagen scandal. New York: WW Norton \& Company.

Farhang, S. (2010). The litigation state: public regulation and private lawsuits in the U.S. Princeton: Princeton University Press.

Financial Conduct Authority. (2016). Our future mission. London.

Financial Conduct Authority. (2018). Our approach to enforcement. London.

Financial Ombudsman Service. (2017). Fairness in a changing world. In Annual review 2016/2017. London: Financial Ombudsman Service.

Haidt, J. (2012). The righteous mind. Why good people are divided by politics and religion. London: Penguin Books.

Heffernan, M. (2011). Wilful blindness. Why we ignore the obvious at our peril. New York: Simon \& Schuster.

Helmreich, R. L. (1999). Building safety on the three cultures of aviation. In Proceedings if the IATA human factors seminar (pp. 39-43). Bangkok.

Hodges, C. (2001). Multi-party actions. Oxford: Oxford University Press.

Hodges, C. (2008). The reform of class and representative actions in European legal systems. A new framework for collective redress. Oxford: Hart Publishing.

Hodges, C. (2009). From class actions to collective redress. Civil Justice Quarterly, 28(1), 41-66.

Hodges, C. (2010). Collective redress in Europe: the new model. Civil Justice Quarterly, 7, 370.

Hodges, C. (2011). European competition enforcement policy: integrating restitution and behaviour control. World Competition, 34(3), 383-396.

Hodges, C., Benöhr, I., \& Creutzfeldt-Banda, N. (2012). Consumer ADR in Europe. Oxford: Hart Publishing.

Hodges, C. (2014). Consumer redress: ideology and empiricism. In K. Purnhagen \& P. Rott (Eds.), Varieties of European economic law and regulation. Festschrift for Hans Micklitz. Berlin: Springer.

Hodges, C. (2015a). Mass collective redress: Consumer ADR and regulatory techniques. European Review of Private Law, 5, 829.

Hodges, C. (2015b). Law and corporate behaviour: integrating theories of regulation, enforcement, culture and ethics. Oxford: Hart Publishing. ch 10.

Hodges, C. (2015c). US class actions: Promise and reality (EUI Florence Working Paper 2015/36 (ERC ERPL 14)). San Domenico di Fiesole: European University Institute. Available at http://hdl.handle.net/1814/36536; available in German at http://hdl.handle.net/1814/464646

Hodges, C., \& Creutzfeldt, N. (2016). Transformations in public and private enforcement. In H.-W. Micklitz \& A. Wechsler (Eds.), The transformation of enforcement. Oxford: Hart Publishing.

Hodges, C., \& Steinholtz, R. (2017). Ethical business practice and regulation: a behavioural and values-based approach to compliance and enforcement. Oxford: Hart Publishing.

Hodges, C., \& Voet, S. (2018). Delivering collective redress: new technologies. Oxford: Hart Publishing.

Institute for Legal Reform. (2017a). The growth of collective redress in the EU. In A survey of developments in 10 Member States. Washington, DC: US Chamber Institute for Legal Reform. 
Institute for Legal Reform. (2017b). Collective redress tourism. In Preventing forum shopping in the EU. Washington, DC: US Chamber Institute for Legal Reform.

Institute for Legal Reform. (2017c). Supporting safeguards. EU consumer attitudes towards collective actions and litigation funding. Washington, DC: US Chamber Institute for Legal Reform.

Kagan, R. A. (2001). Adversarial legalism: the American way of law. Boston: Harvard University Press.

Kahneman, D. (2011). Thinking, fast and slow. London: Allen Lane.

Kramer, X., \& Kakiuchi, S. (2015). Austerity in civil procedure and the role of simplified procedures. Erasmus Law Review, 8, 139.

Lagasse, F., \& Palumbo, M. (2013). Ghislenghien: catastrophe technologique au carrefour du droit pénal et du droit civil. Droit pénal de l'entreprise, 4, 37-40.

Leuven Report (2007). An analysis and evaluation of alternative means of consumer redress other than redress through ordinary judicial proceedings. Final report. Leuven: The Study Centre for Consumer Law, Centre for European Economic Law Katholieke Universiteit Leuven. http://www.eurofinas. org/uploads/documents/policies/OTHER\%20POLICY\%20ISSUES/comparative_report_en.pdf.

Macleod, S., \& Hodges, C. (2017). Redress schemes for personal injuries. Oxford: $\bar{H}$ art Publishing.

McCune, D., Lewis, C., \& Arendt, D. (2011). Safety culture in your safety management system. In A. J. Stolzer, C. D. Halford, \& J. J. Goglia (Eds.), Implementing safety management systems in aviation. Farnham: Ashgate.

Money-Kyrle, R. (2015). Collective enforcement of consumer rights in the United Kingdom. In Schmidt-Kessel, M., Strünck, C. \& Kramme, M. (Eds.), Im namen der verbraucher? Kollektive rechtsdurchsetzung in Europa. Jena: Schriften zu Verbraucherrecht und Verbraucherwissenschaften, Band 5 Jenaer Wissenschaftliche Verlagsgesellschaft.

Moreau, P. (2010). Extraits du jugements du 22 février 2010 du Tribunal correctionnel de Tournai dans l'affaire de la catastrophe de Ghislenghien-note introductive. Revue pratique de l'immobilier, 1, 215.

Onțanu, E. A. (2017). Cross-border debt recovery in the EU. A comparative and empirical study of the use of the European uniform procedures. Cambridge: Intersentia.

Philippe, D. (2015). La responsabilité civile en matière d'énergie - volume 2: L'affaire de Ghislenghien, l'indemnisation du client final envers le gestionnaire de réseau et la responsabilité civile nucléaire. In X, Responsabilités. Traité théorique et pratique, Titre III, Livre 32bi. (1) 8, no 107. lphen aan den Rijn: Kluwer.

Schack, H. (2017). Internationales Zivilverfahrensrecht, 7th edition. Marginal no. 625.

Tamuz, M. (2001). Learning disabilities for regulators. The perils of organizational learning in the air transportation industry. Administration \& Society, 33(3), 276-302.

UNCTAD. (2017). Manual on consumer protection. Geneva: United Nations Conference on Trade and Development.

Voet, S. (2013a). Public enforcement and A(O)DR as mechanisms for resolving mass problems: a Belgian perspective. In C. Hodges \& A. Stadler (Eds.), Resolving mass disputes: ADR and settlement of mass claims (pp. 280-282). Cheltenham: Edward Elgar.

Voet, S. (2013b). Cultural dimensions of group litigation: the Belgian case. Georgia Journal of International \& Comparative Law, 41, 433-479.

Voet, S. (2015). Consumer collective redress in belgium: class actions to the rescue? European Business Organization Law Review, 1, 121-143.

Voet, S. (2017). 'Where the wild things are' reflections on the state and future of European collective redress. In M. Loos \& A. Keirse (Eds.), Waves in contract and liability law in three decades of ius commune. Cambridge: Intersentia/Metro.

Woopen, H. (2018a) Kollektiver Rechtsschutz-Das Desaster naht. Internationale Zeitschrift für Wirtschaftsrecht. 2018.

Woopen, H. (2018b). Kollektiver rechtsschutz-Ziele und wege. Neue Juristische Wochenschrift, $133-138$.

\section{Affiliations}

\section{Hodges ${ }^{1}$}

1 Centre for Socio-Legal Studies, Manor Road, Oxford OX1 3UQ, UK 